1 ANALYTICAL SCIENCE

$2 \&$ TECHNOLOGY

Vol. 26, No. 6, 364-374, 2013

http://dx.doi.org/10.5806/AST.2013.26.6.364

\title{
Seasonal concentrations and emission characteristics of odorous compounds produced from swine facilities in Jeju Island
}

\author{
Jung-Min Song, Hyo-Sun Yang, Han-Jong Ko', Young Ju Kim², \\ Ki Youn $\mathrm{Kim}^{3}$ and Chang-Hee Kang ${ }^{4, \star}$ \\ Jeju Environment Research Institute Co., Ltd., Jeju 695-791, Korea \\ ${ }^{1}$ Division of Livestock Policy, Jeju Special Self-Governing Province, Jeju 690-700, Korea \\ ${ }^{2}$ Jeju Biodiversity Research Institute, Jeju Technopark, Jeju 699-943, Korea \\ ${ }^{3}$ Department of Industrial Health, Catholic University of Pusan, Pusan 609-757, Korea \\ ${ }^{4}$ Department of Chemistry, Jeju National University, Jeju 690-756, Korea \\ (Received August 26, 2013; Revised September 30, 2013; Accepted October 8, 2013)

\section{제주지역 양돈시설에서 발생하는 악취물질의} \\ 계절별 농도 및 배출 특성 \\ 송정민 · 양효선 · 고한종 1 김영주 ${ }^{2} \cdot$ 김기연 ${ }^{3} \cdot$ 강창희 ${ }^{4, \star}$ \\ (주)제주환경자원연구소, 1제주도청 축정과, ${ }^{2}$ 제주테크노파크 생물종다양성연구소, \\ ${ }^{3}$ 부산가톨릭대학교 산업보건학과, ${ }^{4}$ 제주대학교 화학과 \\ (2013. 8. 26. 접수, 2013. 9. 30. 수정, 2013. 10. 8. 승인)
}

\begin{abstract}
The major ten odorous compounds have been analyzed from four swine facilities in Jeju Island, in order to investigate the emission characteristics and odor contribution by different ventilation systems and manure treating types. From the study, the concentrations of $\mathrm{NH}_{3}$ and TMA were high at the enclosed ventilation and scraper type facilities in winter season, and the sulfur compounds $\left(\mathrm{H}_{2} \mathrm{~S}, \mathrm{CH}_{3} \mathrm{SH}\right.$, DMS, DMDS) as well as volatile fatty acids (PA, n-BA, n-VA, iso-VA) showed high concentrations at the enclosed ventilation type facilities during winter season. The concentrations of nitrogen and sulfur compounds were high at slurry manure treat facilities. However, the volatile fatty acids (VFA) were relatively high in the scraper type swine facilities. The odor quotients of n-BA were high at four swine facilities, therefore the volatile fatty might be considered as the major odor causing compounds. Moreover the sum of odor quotient (SOQ) was high at the enclosed ventilation and scraper type facilities, and the odor contributions by volatile fatty acids were high in all swine facilities.

요 약: 주요 악취물질 10 종을 분석하여 환기방식과 분뇨수거방식이 다른 제주지역 4 개 돈사의 악취 물질 배출특성과 기여도를 조사하였다. 연구 결과 질소계열 $\left(\mathrm{NH}_{3}, \mathrm{TMA}\right)$ 은 겨울철에 농도가 높았고, 무창 형 스크레퍼방식이 다른 돈사에 비해 농도가 높았다. 황화합물 $\left(\mathrm{H}_{2} \mathrm{~S}, \mathrm{CH}_{3} \mathrm{SH}, \mathrm{DMS}, \mathrm{DMDS}\right)$ 과 휘발성 지 방산(PA, n-BA, n-VA, iso-VA) 역시 겨울철에 높고, 무창형 스크레퍼와 무창형 슬러리방식 돈사에서 다
\end{abstract}

Corresponding author

Phone : +82-(0)64-754-3545 Fax : +82-(0)64-756-3561

E-mail : changhee@jejunu.ac.kr 
Seasonal concentrations and emission characteristics of odorous compounds produced from swine facilities in Jeju Island 365

소 높은 농도를 나타내었다. 환기방식별로는 무창형 돈사가 개방형돈사에서 비해 농도가 더 높고, 분뇨 수거 방식별로는 슬러리방식에서 질소와 황 계열의 농도가 높고 스크레퍼방식에서는 휘발성 지방산 계 열이 상대적으로 더 높은 것으로 조사되었다. 악취지수는 4 개의 돈사에서 모두 n-BA 성분이 높게 나타 나 휘발성 지방산이 주요 악취원인물질로 조사되었다. 그리고 총악취지수(SOQ)는 무창형 스크레퍼방식 돈사에서 더 높고, 악취기여도는 휘발성 지방산이 모든 돈사에서 높은 결과를 나타내었다.

Key words: odorous compound, Jeju Island, swine facilities, sum of odor quotient, odor contribution

\section{1. 서 론}

제주도는 천혜의 자연경관과 청정한 대기질을 유지 하고 있는 관광지이다. 그러나 중산간 지역을 중심으 로 널리 분포하고 있는 양돈시설과 축산폐기물 처리 시설에서 발생하는 악취 때문에 심미적으로 나쁜 영 향을 미치고 있어서 대기질 관리에 어려움을 겪고 있 다. 악취물질은 기존의 대기오염물질과는 달리 직접적 으로 주민들에게 피해를 주고 있어서 최근 심각한 대 기오염문제로 인식되고 있고, 민원발생의 원인으로 부 각되고 있다. 특히 제주지역의 양돈산업은 제주지역 의 특화정책에 따라 꾸준이 증가하고 있는 추세이고, 이에 따른 악취 민원은 2006년 46건에서 2011년 92건 으로 지속해서 증가하고 있다. 2

악취는 자극성 있는 기체상 물질이 사람의 후각을 자극하여 불쾌감과 혐오감을 주며 그 종류에 따라 발 생기원이 다르다. 또한 발생량을 어느 정도 저감시키 더라도 극미량만으로 취기를 유발시키기 때문에 이에 대한 대책과 방지에 많은 어려움을 겪고 있다. 사람의 후각 감각은 개인별로 다르기 때문에 악취의 질과 강 도를 감지하는 정도는 큰 차이를 보이고, 관능법에 의 해 그 정도를 평가하는 것은 쉽지 않다. 특히 돈사 내 에서 발생된 악취는 인체에 정신적, 생리적 스트레스 를 유발시켜 메스꺼움, 두통, 식욕감퇴, 호흡곤란, 알 레르기 현상 등의 자가 반응을 나타내기도 한다.3-4

가장 대표적인 악취 물질은 양돈장 돈사 내의 사료 와 돼지 배설물의 부패로 발생되고 있다. 그리고 주로 암모니아, 휘발성 지방산, 황화합물, 트리메틸아민과 같은 저급아민류 등이 악취의 원인 물질로 알려져 있 다. ${ }^{5-7}$ 대체적으로 양돈 분뇨에서 발생되는 악취유발 물질은 총 168 가지 정도가 알려져 있으며, 이 중 30 여 종은 $0.001 \mathrm{mg} \mathrm{m}^{-3}$ 이하의 최소감지농도로도 악취를 발생한다. ${ }^{8}$

양돈장에서 발생하는 악취는 돼지의 성장단계에 따 라 분만돈이 $31 \%$, 모돈이 $23 \%$ 로 가장 심한 것으로
조사되고 있다. 또 악취는 사육시설별 분뇨처리 방식 에 따라 슬러리 처리가 약 $40 \%$ 로 가장 높은 비중을 차지하고 있다. ${ }^{9}$ 특히 돈사 작업장의 대표적인 악취물 질은 $\mathrm{NH}_{3}$ 와 $\mathrm{H}_{2} \mathrm{~S}$ 이며, 발생량이 다른 작업장에 비해 상대적으로 높은 경향을 보인다. 일반적으로 돈사 내 부에서 $\mathrm{NH}_{3}$ 는 $5.7 \mathrm{ppmv}$ 정도이고, 다음으로 $\mathrm{H}_{2} \mathrm{~S}$ 가 $0.9 \mathrm{ppmv}$ 정도로 높은 농도를 나타낸다. 그러나 부지 경계선에서는 이들 두 성분의 농도가 각각 $2.5,0.038$ $\mathrm{ppmv}$ 정도로 $\mathrm{NH}_{3}$ 가 약 $56 \%, \mathrm{H}_{2} \mathrm{~S}$ 가 약 $96 \%$ 정도 감 소하는 것으로 조사되고 있다. ${ }^{10}$ 계절별로는 외부 기 온이 낮은 동절기에 실내 온도 유지를 환기를 최소화 시키기 때문에 종종 노출기준을 초과하여 작업자의 인체에 피해를 줄 수 있다. ${ }^{11-12}$

우리나라 양돈농가 축사형태는 주로 외부와 차단된 밀폐형 돈사와 외부에 노출된 윈치커튼형 돈사 구조 를 채택하고 있다. 그리고 분뇨수거방식은 분과 뇨가 혼합된 슬러리 형, 분과 뇨를 분리하여 처리하는 스크 레퍼 형, 그리고 슬러리와 스크레퍼 형이 혼합된 형태 등으로 되어 있다. 이들 분뇨수거방식은 비교적 복잡 하고 다양한 구조로 되어 있으며, 이들 돈사 각각에서 발생되는 주요 악취성분을 비교할 필요가 있다. 이에 본 연구에서는 제주지역 양돈시설의 축사형태와 분뇨 수거방식에 따라 발생되는 악취물질을 분석함으로써 양돈시설별 주요 악취유발물질 특성과 악취 기여도를 상호 비교하였다. 그리고 그 결과를 기초로 제주지역 양돈시설에서 발생하는 악취물질을 효과적으로 저감시 키기 위한 정보와 자료를 제공하고자 하였다.

\section{2. 연구 방법}

\section{1. 악취 시료 채취}

제주 지역에 위치한 돈사 4 개소를 대상으로 2011 년 12월부터 2012년 11월까지 2 회에 걸쳐 계절별로 각 3 회씩 총 6 회의 악취시료를 채취하였다. 양돈시 설 선정은 돈사의 환기방식과 돈사 내부의 분뇨 수거

Vol. 26, No. 6, 2013 
Table 1. Profile of the swine facilities in this study

\begin{tabular}{|c|c|c|}
\hline Swine & $\begin{array}{c}\text { Manure handling } \\
\text { characteristics }\end{array}$ & $\begin{array}{l}\text { Ventilation } \\
\text { system }\end{array}$ \\
\hline $\mathrm{J}$ Farm & $\begin{array}{l}\text { Manure removal system } \\
\text { by scraper }\end{array}$ & Enclosed type \\
\hline K Farm & $\begin{array}{l}\text { Manure removal system } \\
\text { by scraper }\end{array}$ & Winch-curtain \\
\hline N Farm & $\begin{array}{l}\text { Deep-pit manure system } \\
\text { with slats }\end{array}$ & Enclosed type \\
\hline S Farm & $\begin{array}{l}\text { Deep-pit manure system } \\
\text { with slats }\end{array}$ & Winch-curtain \\
\hline
\end{tabular}

방식를 고려하여 무창형 스크레퍼방식(J 농장), 개방 형 스크레퍼방식(K 농장), 무창형 슬러리방식( $\mathrm{N}$ 농장), 그리고 개방형 슬러리방식(S 농장)을 선택하였으며 돈 사의 제원은 Table 1 과 같다. 또한 시료는 데이터의 객관성과 대표성 확보를 위해 맑은 날 동일한 시간대 에 2 시간 동안(10:00 $\mathrm{AM} 12: 00 \mathrm{PM})$ 돈사 내부의 정 중앙에서 채취하였다. 그리고 시료는 악취가 가장 많 이 발생하는 것으로 알려진 비육돈사를 대상으로 채 취하였다.

본 연구의 대상 악취물질은 양돈시설에서 주요 발 생원으로 알려진 질소화합물 계열의 Ammonia $\left(\mathrm{NH}_{3}\right)$ 와 Trimethylamine (TMA), 황화합물 계열의 Hydrogensulfide $\left(\mathrm{H}_{2} \mathrm{~S}\right)$, Methylmercaptan $\left(\mathrm{CH}_{3} \mathrm{SH}\right)$, Dimethylsulfide (DMS), Dimethyldisulfide (DMDS), 그리고 2010 년에 지정악취물질로 추가된 휘발성 지방산 Propionic acid (PA), n-Butyric acid (n-BA), n-Valeric acid (n$\mathrm{VA}$ ), iso-Valeric acid (iso-VA) 등 10 종이다.

암모니아 분석용 시료는 용액흡수법으로 채취하였
다. 암모니아 흡수용액( $0.5 \%$ Boric acid) $20 \mathrm{~mL}$ 를 채 운 흡수병(임핀저) 2 개를 직렬로 연결한 후 흡입펌프 (Sibata, KP-10O, Japan)를 연결하여 $10 \mathrm{~L} / \mathrm{min}$ 유속으 로 5 분 간, 총 $50 \mathrm{~L}$ 의 시료공기를 통과시켰다. 또한 황화합물은 Polyester aluminum sampling bag (Top Trading ENG, 10 L, Korea)과 진공흡인상자(Supelco, $10642, \mathrm{USA})$ 를 이용하여 간접흡인방식으로 채취하였고, $2 \mathrm{~L} / \mathrm{min}$ 의 유속으로 5 분 간, 총 $10 \mathrm{~L}$ 의 공기시료를 포 집하였다. 그리고 이렇게 2 개의 임핀저에 채취한 흡수 용액은 부피플라스크에 옮긴 후 최종적으로 $50 \mathrm{~mL}$ 로 희석하였고, 이를 분석용 시료로 사용하였다. TMA와 휘발성 지방산 역시 암모니아 동일한 방식의 용액흡수 법으로 시료를 채취하였고, 흡수액은 각각 $0.1 \mathrm{M}$ 황산 용액과 $0.1 \mathrm{M}$ 수산화나트륨용액을 사용하였다.

\section{2. 악취물질 분석}

암모니아는 인도페놀법으로 시료를 발색시킨 후 $640 \mathrm{~nm}$ 에서 흡광도를 측정하여 정량분석하였다. 앞에 서 용액흡수법으로 채취한 흡수액 $10 \mathrm{~mL}$ 에 페놀펜타 시아노니트로실철(III)산 나트륨과 차아염소산나트륨 을 가하여 1 시간 동안 발색시킨 후 흡광도를 측정하 였다. 이때 흡광도는 자외-가시선분광광도계(Sinco, S3100, Korea)를 사용하였다.

황화합물 시료는 Thermal desorber System (Markes International, Unity $2^{\mathrm{TM}}$-Air Server, $\mathrm{UK}$ )이 부착된 $\mathrm{GC}$ 를 이용하여 Table 2의 기기조건으로 분석하였다. 황 화합물 시료를 $-15^{\circ} \mathrm{C}$ 에서 응축한 후 이를 열탈착시켜 $\mathrm{GC}$ 에 주입하였고, 시료를 불꽃광도검출기가 부착된 GC-FPD (Shimadzu, 2010 plus, Japan)로 분석하였다.

TMA는 미량고체상추출법(SPME, Solid Phase Micro

Table 2. Instrumental conditions for analyzing sulfur compounds in swine facilities

\begin{tabular}{cll}
\hline \hline \multicolumn{1}{c}{ Instrument } & \multicolumn{1}{c}{ Operation Conditions } \\
\hline & Sampling flow & $50 \mathrm{~mL} / \mathrm{min}$ \\
& Sampling time & $10 \mathrm{~min}$ \\
Thermal Desorber & Coldtrap & Hydrogen Sulphide \\
(Unity2 ${ }^{\mathrm{TM}}$-Air Server) & Coldtrap low temperature & $-15^{\circ} \mathrm{C}$ \\
& Coldtrap high temperature & $250{ }^{\circ} \mathrm{C}$ \\
& Coldtrap hold time & $5 \mathrm{~min}$ \\
\hline GC/FPD & Column info & Varian CP-SIL $5 \mathrm{CB}$ \\
$(\mathrm{GC}-2010$ plus $)$ & Initial temperature & $(60 \mathrm{~m} \times 0.32 \mathrm{~mm} \times 5 \mu \mathrm{mm})$ \\
& Temperature Rate & $50{ }^{\circ} \mathrm{C}(7 \mathrm{~min})$ \\
& Final temperature & $10^{\circ} \mathrm{C} / \mathrm{min}$ to $280^{\circ} \mathrm{C}$ \\
& Detector temperature & $280{ }^{\circ} \mathrm{C}(5 \mathrm{~min})$ \\
\hline
\end{tabular}


Seasonal concentrations and emission characteristics of odorous compounds produced from swine facilities in Jeju Island 367

Table 3. Instrumental conditions for analyzing trimethylamine in swine facilities

\begin{tabular}{lll}
\hline \multicolumn{1}{c}{ Instrument } & & Operation Conditions \\
\hline & Preincubation time & $10 \mathrm{~min}$ \\
SPME System & Incubation temperature & $35^{\circ} \mathrm{C}$ \\
(AOC-5000 plus) & Extraction time & $15 \mathrm{~min}$ \\
& Agitator speed & $500 \mathrm{rpm}$ \\
& Desorption time & $8 \mathrm{~min}$ \\
\hline GC/FTD & Column info & Varian CP-Volamine \\
$(\mathrm{GC}-2010$ plus $)$ & Injector temperature & $(60 \mathrm{~m} \times 0.32 \mathrm{~mm} \times 0.45 \mu \mathrm{m})$ \\
& Initial temperature & $250{ }^{\circ} \mathrm{C}$ \\
& Temperature rate & $50{ }^{\circ} \mathrm{C}(5 \mathrm{~min})$ \\
& Final temperature & $10{ }^{\circ} \mathrm{C} / \mathrm{min}$ to $230{ }^{\circ} \mathrm{C}$ \\
& Detector temperature & $230^{\circ} \mathrm{C}(3 \mathrm{~min})$ \\
\end{tabular}

Table 4. Instrumental conditions for analyzing volatile fatty acids in swine facilities

\begin{tabular}{|c|c|c|}
\hline Instrument & & itions \\
\hline \multirow{5}{*}{$\begin{array}{l}\text { SPME System } \\
\text { (AOC-5000 plus) }\end{array}$} & Preincubation time & $10 \mathrm{~min}$ \\
\hline & Incubation temperature & $90{ }^{\circ} \mathrm{C}$ \\
\hline & Extraction temperature & $15 \mathrm{~min}$ \\
\hline & Agitator speed & $500 \mathrm{rpm}$ \\
\hline & Desorption temperature & $8 \min$ \\
\hline \multirow{6}{*}{$\begin{array}{l}\text { GC/FID } \\
\text { (GC-2010 plus) }\end{array}$} & Column info & $\begin{array}{l}\text { Agilent HP-FFAP } \\
(30 \mathrm{~m} \times 0.53 \mathrm{~mm} \times 1 \mu \mathrm{m})\end{array}$ \\
\hline & Injector temperature & $250{ }^{\circ} \mathrm{C}$ \\
\hline & Initial temperature & $100{ }^{\circ} \mathrm{C}(2 \mathrm{~min})$ \\
\hline & Temperature rate & $10{ }^{\circ} \mathrm{C} / \mathrm{min}$ to $220^{\circ} \mathrm{C}$ \\
\hline & Final temperature & $220^{\circ} \mathrm{C}(8 \mathrm{~min})$ \\
\hline & Detector temperature & $300{ }^{\circ} \mathrm{C}$ \\
\hline
\end{tabular}

Extraction)으로 전처리한 후 GC-FTD로 분석하였다. 앞에서 용액흡수법으로 채취한 흡수액 $4 \mathrm{~mL}$ 를 바이 알에 옮기고, $50 \% \mathrm{KOH} 5 \mathrm{~mL}$ 를 주입하여 PTFE/ Silicone septum으로 밀봉하였다. 그리고 SPME System (Shimazu, AOC-5000 plus, Japan) 내에서 $35^{\circ} \mathrm{C}$ 로 10 분 간 교반하였다. 이후 상층부의 기체상 $\mathrm{TMA}$ 를 SPME Fiber (carboxen/polydimethylsiloxane, Supelco, 75 $\mu \mathrm{m}, \mathrm{USA}$ )로 15 분 간 흡착시킨 후 불꽃열이온화검출 기가 설치된 GC-FTD (Shimadzu, 2010 plus, Japan)에 주입하여 정량분석하였다. 이때 SPME System 전처리 및 GC-FTD 분석조건은 Table 3과 같다.

휘발성 지방산 역시 $\mathrm{TMA}$ 와 마찬가지로 미량고체 상추출법으로 전처리하여 GC-FID로 분석하였다. 용 액흡수법으로 채취한 흡수액 $5 \mathrm{~mL}$ 를 바이알에 옮겨 염화나트륨 $1.78 \mathrm{~g}$, 진한 $\mathrm{HCl} 100 \mu \mathrm{L}$ 를 가하여 $\mathrm{pH} 1$ 로 조절한 후 PTFE/Silicone septum으로 밀봉하였다.
그리고 SPME System에서 $90{ }^{\circ} \mathrm{C}$ 로 10 분 간 교반한 후 바이알 상층부의 기체상 지방산을 SPME Fiber로 흡착시켜 GC-FID에 주입, 분석하였다. 이때 시료의 SPME System 전처리 및 GC-FID 분석조건은 Table 4 와 같다.

이러한 방법으로 암모니아, 황화합물, 트리메틸아민, 휘발성 지방산 10 종은 각각 인도페놀법, GC-FPD, $\mathrm{GC}-\mathrm{FTD}, \mathrm{GC}-\mathrm{FID}$ 를 이용하여 분석하였다. 그리고 분 석 데이터의 신뢰도는 방법검출한계 $(\mathrm{MDL})$ 를 구하여 평가 하였다. $\mathrm{MDL}$ 은 암모니아, 황화합물, 트리메틸아 민, 휘발성 지방산의 $0.4 \mu \mathrm{g} / \mathrm{mL}, 1.0 \mathrm{nmol} / \mathrm{mol}, 1.0 \mathrm{ng} /$ $\mathrm{mL}, 0.1 \mu \mathrm{g} / \mathrm{mL}$ 표준용액 각각을 7 회 반복 분석하여 표준편차를 구하고 이 값에 Student-t (3.143)를 곱하여 $98 \%$ 신뢰수준으로 측정하였다. 또한 데이터의 재현성 확인은 7 회 반복 분석한 데이터로부터 변동계수(CV) 를 구하여 확인하였고, 이렇게 구한 분석 데이터의 방 
Table 5. Method detection limit (MDL) and coefficient of variation $(\mathrm{CV})$ for analyzing odorous compounds $(\mathrm{n}=7)$

\begin{tabular}{lcc}
\hline \hline \multicolumn{1}{c}{ Compound } & \multicolumn{1}{c}{ MDL } & $\mathrm{CV}(\%)$ \\
\hline Ammonia $\left(\mathrm{NH}_{3}\right)$ & $0.036 \mathrm{ppmv}(1.24 \mu \mathrm{g})$ & 2.0 \\
Trimethylamine (TMA) & $0.070 \mathrm{ppbv}(8.42 \mathrm{ng})$ & 5.1 \\
Hydrogen sulfide ( $\left.\mathrm{H}_{2} \mathrm{~S}\right)$ & $0.475 \mathrm{ppbv}(0.33 \mathrm{ng})$ & 9.7 \\
Methyl mercaptan $\left(\mathrm{CH}_{3} \mathrm{SH}\right)$ & $0.541 \mathrm{ppbv}(0.53 \mathrm{ng})$ & 9.8 \\
Dimethyl sulfide (DMS) & $0.644 \mathrm{ppbv}(0.82 \mathrm{ng})$ & 9.9 \\
Dimethyl disulfide (DMDS) & $0.266 \mathrm{ppbv}(0.54 \mathrm{ng})$ & 4.5 \\
Propionic acid (PA) & $0.014 \mathrm{ppmv}(2.15 \mu \mathrm{g})$ & 11.2 \\
n-butyric acid (n-BA) & $0.003 \mathrm{ppmv}(0.47 \mu \mathrm{g})$ & 2.6 \\
iso-valeric acid (iso-VA) & $0.005 \mathrm{ppmv}(0.99 \mu \mathrm{g})$ & 5.5 \\
n-valeric acid (n-VA) & $0.006 \mathrm{ppmv}(1.24 \mu \mathrm{g})$ & 7.8 \\
\hline
\end{tabular}

법검출한계와 변동계수를 Table 5에 수록하였다.

\section{3. 결과 및 고찰}

\section{1. 암모니아 농도}

제주지역 양돈시설의 돈사 환기방식과 분뇨 수거방 식이 다른 4 개소의 비육돈사 내부 정중앙에서 시료 채취한 암모니아 성분 측정결과는 Fig. 1 과 같다. $\mathrm{NH}_{3}$ 성분의 계절별 평균농도는 겨울철 $(26.1 \mu \mathrm{mol} /$ $\mathrm{mol})$ 에 가장 높게 나타났으며, 다음으로 봄 $(19.1 \mu \mathrm{mol} /$ $\mathrm{mol})$, 가을 $(14.6 \mu \mathrm{mol} / \mathrm{mol})$, 여름 $(8.6 \mu \mathrm{mol} / \mathrm{mol})$ 순으 로 높았다. 그리고 돈사방식별로는 무창형 스크레퍼방 식 $(\mathrm{J}$ 농장 $)>$ 개방형 슬러리방식 $(\mathrm{S}$ 농장 $)>$ 무창형 슬 러리방식 $(\mathrm{N}$ 농장 $)>$ 개방형 스크레퍼방식 $(\mathrm{K}$ 농장 $)$ 순 으로 높은 농도를 나타내었다. 또한 각 계절별로 돈사 방식에 따른 농도를 비교해 본 결과, 겨울과 여름철에 는 무창형 스크레퍼방식에서 암모니아가 더 높은 농

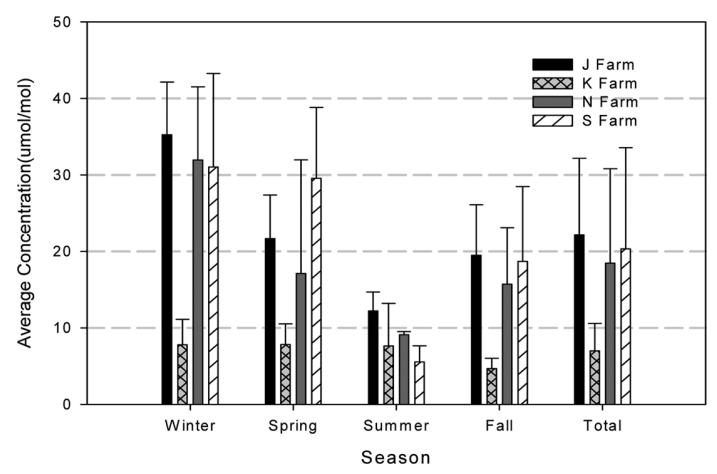

Fig. 1. Seasonal average concentrations of $\mathrm{NH}_{3}$ in swine facilities.
도를 보이지만, 봄과 가을철에는 개방형 슬러리방식 돈사에서 상대적으로 높은 농도를 나타내었다. 이때 봄철에 개방형 슬러리방식인 $\mathrm{S}$ 농장에서 농도가 높은 것은 측정 당시 돈사 외부온도가 낮아서 돼지 폐사 예방을 위해 외창을 밀폐했기 때문인 것으로 보인다. 또 외부공기의 유입이 차단되면서 돈사 내부와 외부 의 온도차가 크기 때문에 내부의 습도가 상승한 것도 농도 증가의 한 원인이라고 생각된다. 또한 여름철과 개방형 스크레퍼방식(K 농장)외의 모든 돈사에서 암 모니아가 $15 \mathrm{ppmv}$ 이상의 농도를 나타내었다. 이러한 농도는 가축의 성장을 저해하고, 밀폐된 공간에서는 호흡기 계통의 질병을 유발할 수 있는 수준으로 보고 되고 있다. ${ }^{13}$

\section{2. 트리메틸아민 농도}

트리메틸아민(TMA)의 농도를 4 개 돈사에서 측정 한 결과를 Fig. 2에 나타내었다. TMA 성분의 계절별 농도는 겨울철에 $52.983 \mathrm{nmol} / \mathrm{mol}$ 로 가장 높았다. 그 리고 다음으로 봄 $32.512 \mathrm{nmol} / \mathrm{mol}$, 가을 31.063 $\mathrm{nmol} / \mathrm{mol}$, 여름 $13.598 \mathrm{nmol} / \mathrm{mol}$ 순으로 높았으며, 동 일한 질소계열의 암모니아와 유사한 계절변화 추세를 나타내었다. 또한 돈사방식별 비교에서는 무창형 스크 레퍼방식 $(\mathrm{J}$ 농장 $)>$ 개방형 슬러리방식 $(\mathrm{S}$ 농장 $)>$ 무 창형 슬러리방식 $(\mathrm{N}$ 농장 $)>$ 개방형 스크레퍼방식 $(\mathrm{K}$ 농장) 순으로 농도가 높게 나타났다. 또 각 돈사방식 에 따른 농도변화를 계절별로 비교해 본 결과, 겨울, 여름, 가을철에는 무창형 스크레퍼방식에서 농도가 높 고, 봄철에는 개방형 슬러리방식에서 높은 경향을 나 타내었다. 이처럼 봄철에 개방형 슬러리방식이 무창형 스크레퍼방식보다 농도가 높은 것은 같은 질소계열의 $\mathrm{TMA}$ 성분과 $\mathrm{NH}_{3}$ 성분이 동일한 기원에 의해 발생되

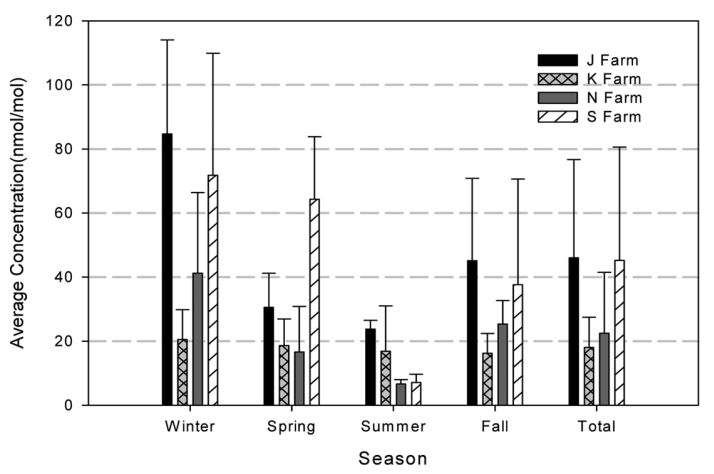

Fig. 2. Seasonal average concentrations of TMA in swine facilities. 
기 때문인 것으로 판단된다. 이러한 기원을 확인하기 위하여 두 성분의 상관관계를 확인한 결과 상관계수 (r)는 0.88 로 양호한 상관성 보였다. 이러한 결과로 보 아 이들 두 성분은 배출원이 동일한 것으로 추정된다.

\section{3. 황화합물 농도}

주요 황계열 악취물질인 황화수소 $\left(\mathrm{H}_{2} \mathrm{~S}\right)$, 메틸메르캅 탄 $\left(\mathrm{CH}_{3} \mathrm{SH}\right)$, 황화메 틸(DMS), 이황화메 틸(DMDS)의 농도를 4 개 돈사에서 측정하였고, 그 결과를 Fig. 3 에 비교하였다. 그림의 결과와 같이 $\mathrm{H}_{2} \mathrm{~S}$ 성분의 계절 별 평균농도는 겨울철에 $505.22 \mathrm{nmol} / \mathrm{mol}$ 로 가장 높 았고, 다음으로 봄 $195.06 \mathrm{nmol} / \mathrm{mol}$, 가을 184.59 $\mathrm{nmol} / \mathrm{mol}$, 여름 $157.94 \mathrm{nmol} / \mathrm{mol}$ 순으로 높은 경향을 보였다. 그리고 돈사방식별로는 무창형 슬러리방식(N 농장 $)>$ 무창형 스크레퍼방식 $(\mathrm{J}$ 농장 $)>$ 개방형 슬러 리방식(S 농장) > 개방형 스크레퍼방식(K 농장) 순으 로 나타나 이들 성분들은 질소계열과는 다른 경향을 보였다. 또 각 돈사방식에 따른 변화를 계절별로 구분 하여 비교한 결과에서는 사계절 모두 무창형 슬러리 방식에서 높은 농도를 나타내었다. 일반적으로 황화수 소 성분이 다른 계열 성분들에 비해 무창형 돈사에서 농도가 높게 나타나는 것은 황화수소의 비중이 공기

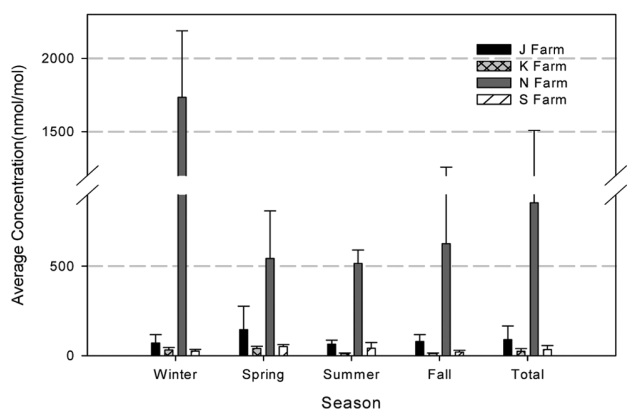

(a) $\mathrm{H}_{2} \mathrm{~S}$

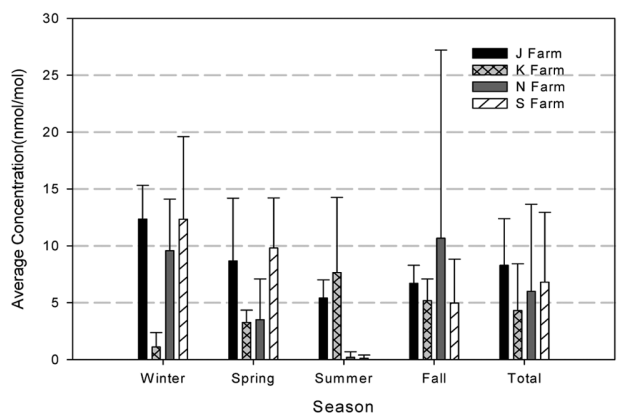

(c) DMS
보다 무겁기 때문에 외기로의 배출이 원활하지 못한데 서 기인하는 것으로 알려져 있다. 이러한 이유로 가축 시설 내부에서도 하부에서 농도가 더 높은 경향을 보 이는 것으로 조사되고 있다. ${ }^{14}$ 이처럼 무창돈사에서 황 화수소 농도가 높은 것은 이 시스템의 경우 공기 순환 이 원활하지 못한 구조이기 때문인 것으로 추정된다.

$\mathrm{CH}_{3} \mathrm{SH}$ 성분의 계절별 평균농도는 겨울철에 19.762 $\mathrm{nmol} / \mathrm{mol}$ 로 가장 높고, 다음으로 봄 $11.871 \mathrm{nmol} / \mathrm{mol}$, 가을 $10.244 \mathrm{nmol} / \mathrm{mol}$, 여름 $9.030 \mathrm{nmol} / \mathrm{mol}$ 순으로 높았다. 그리고 돈사방식별 비교결과에서는 무창형 스 크레퍼방식 $(\mathrm{J}$ 농장 $)>$ 무창형 슬러리방식 $(\mathrm{N}$ 농장 $)>$ 개방형 슬러리방식(S 농장) > 개방형 스크레퍼방식 $(\mathrm{K}$ 농장) 순으로 높은 농도를 나타내었다. 또 계절별로 각 돈사방식에서의 농도를 비교해 본 결과, 사계절 모 두 무창형 스크레퍼방식이 다른 돈사방식에 비해 상 대적으로 더 높은 농도를 나타내었다.

$\mathrm{DMS}$ 는 계절별 평균농도가 겨울철 $8.53 \mathrm{nmol} / \mathrm{mol}$, 가을 $6.88 \mathrm{nmol} / \mathrm{mol}$, 봄 $6.32 \mathrm{nmol} / \mathrm{mol}$, 여름 $3.35 \mathrm{nmol} /$ $\mathrm{mol}$ 로 DMS 역시 겨울철에 가장 높은 경향을 보였다. 또 돈사방식별로 비교해 본 결과에서는 무창형 스크 레퍼방식 $(\mathrm{J}$ 농장 $)>$ 개방형 슬러리방식 $(\mathrm{S}$ 농장 $)>$ 무창 형 슬러리방식 $(\mathrm{N}$ 농장 $)>$ 개방형 스크레퍼방식 $(\mathrm{K}$ 농

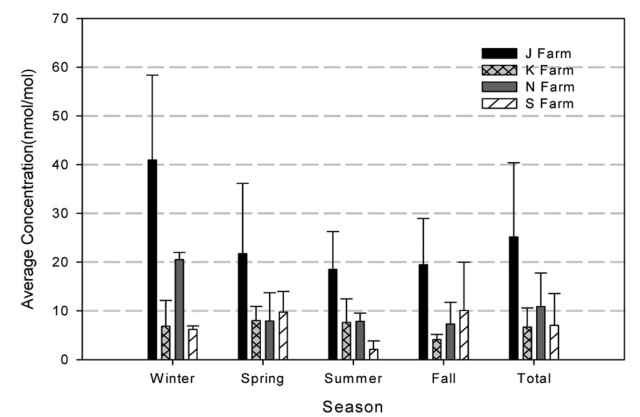

(b) $\mathrm{CH}_{3} \mathrm{SH}$

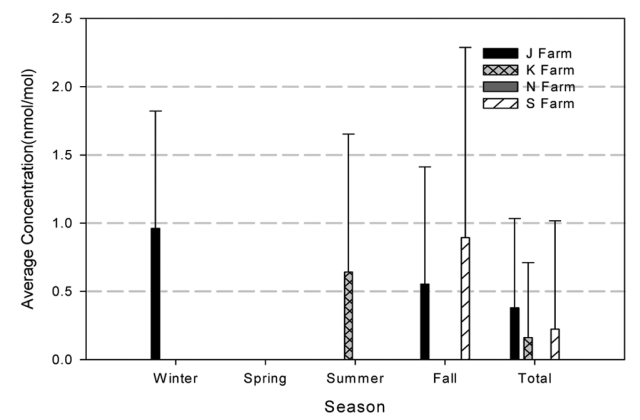

(d) DMDS

Fig. 3. Seasonal average concentrations of $\mathrm{H}_{2} \mathrm{~S}$ (a), $\mathrm{CH}_{3} \mathrm{SH}$ (b), DMS (c), and DMDS (d) in swine facilities. 


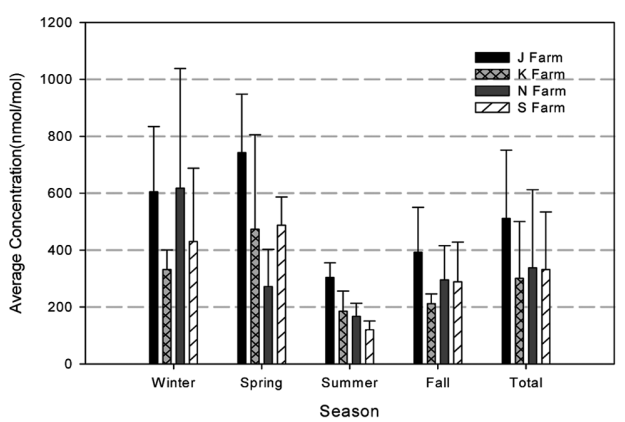

(a) PA

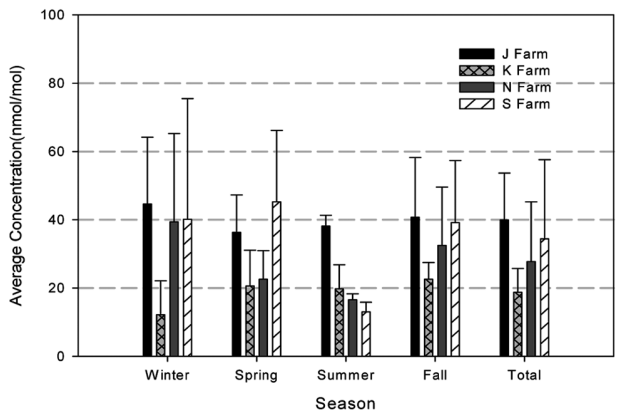

(c) iso-VA

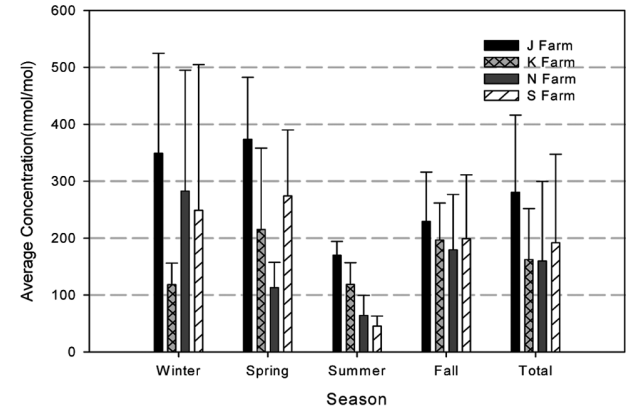

(b) $\mathrm{n}-\mathrm{BA}$

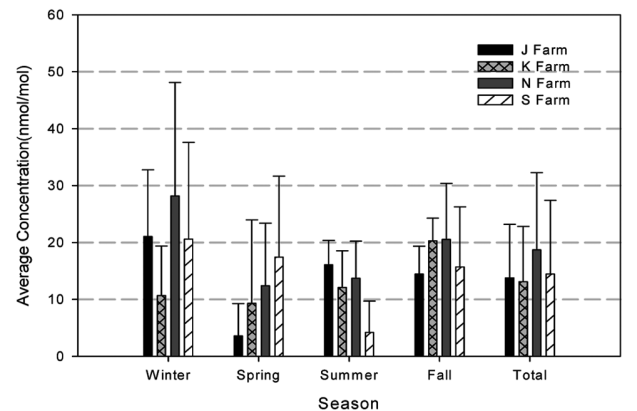

(d) $n-V A$

Fig. 4. Seasonal average concentrations of PA (a), n-BA (b), iso-VA (c), and n-VA (d) in swine facilities.

장) 순으로 농도가 높았다. 또한 계절별로 각 돈사방 식의 농도를 상호 비교한 결과에서는 $\mathrm{DMS}$ 농도가 겨울철에 무창형 스크레퍼방식에서 높았다. 그러나 봄철에는 개방형 슬러리방식, 여름철에는 개방형 스 크레퍼방식, 가을철에는 무창형 슬러리방식의 돈사에 서 농도가 높게 나타나 계절별로 서로 다른 경향을 보이는 것으로 조사되었다.

$\mathrm{DMDS}$ 물질은 4 개 대상 돈사에서 대부분 검출한 계 미만의 농도를 나타내었다. 그러나 겨울철에 무창 형 스크레퍼방식(J 농장)에서는 미량이지만 검출한계 이상의 농도를 나타내었다. 그리고 여름철에 개방형 스크레퍼방식(K 농장), 가을철에 무창형 스크레퍼방식 (J 농장)과 개방형 슬러리방식(S 농장)에서도 미량의 $\mathrm{DMDS}$ 가 검출한계 이상의 농도를 나타내었다. 이러한 $\mathrm{DMDS}$ 는 극미량 농도로 악취공정시험방법에서 제시 한 $9 \mathrm{ppbv}$ 의 배출허용기준을 훨씬 밑도는 수준이다.

\section{4. 휘발성 지방산 농도}

2010년에 새롭게 지정악취물질에 포함된 Propionic acid (PA), n-Butyric acid (n-BA), iso-Valeric acid (iso$\mathrm{VA}), \mathrm{n}$-Valeric acid (n-VA) 4 종의 휘발성 지방산 (VFA)을 분석하였고, 측정한 농도를 Fig. 4에 비교하
였다. 먼저 PA 성분의 계절별 평균농도를 비교해 보 면, 겨울철에 $502.149 \mathrm{nmol} / \mathrm{mol}$ 로 가장 높게 나타났다. 그리고 다음으로 봄 $493.794 \mathrm{nmol} / \mathrm{mol}$, 가을 297.076 $\mathrm{nmol} / \mathrm{mol}$, 여름 $194.082 \mathrm{nmol} / \mathrm{mol}$ 순으로 높은 농도 추세를 보였다. 또한 돈사방식별로 PA 농도를 서로 비교해 본 결과에서는 무창형 스크레퍼방식(J 농장) > 무창형 슬러리방식 $(\mathrm{N}$ 농장 $)>$ 개방형 슬러리방식 $(\mathrm{S}$ 농장) > 개방형 스크레퍼방식(K 농장) 순으로 높은 경향을 나타내었다. 또 계절별로 각 돈사방식에서의 농도를 조사한 결과, 겨울철에는 무창형 슬러리방식에 서 높은 농도를 보이지만, 봄철, 여름철, 가을철에는 무창형 스크레퍼방식의 돈사에서 상대적으로 높은 농 도를 나타내는 것으로 조사되었다.

n-BA는 계절별 평균농도가 겨울철 $249.708 \mathrm{nmol} /$ $\mathrm{mol}$ 로 가장 높았고, 다음으로 봄 $243.913 \mathrm{nmol} / \mathrm{mol}$, 가을 $200.993 \mathrm{nmol} / \mathrm{mol}$, 여름 $99.464 \mathrm{nmol} / \mathrm{mol}$ 순으 로 높았다. 그리고 돈사방식별로 상호 비교해 본 결과 에서는 무창형 스크레퍼방식(J 농장) > 개방형 슬러리 방식 $(\mathrm{S}$ 농장 $)>$ 개방형 스크레퍼방식 $(\mathrm{K}$ 농장 $)>$ 무창 형 슬러리방식(N 농장) 순으로 높은 농도를 나타내었 다. 또한 각 계절별로 돈사방식의 농도를 상호 비교한 결과에서는 사계절 모두 무창형 스크레퍼방식이 다른 
돈사방식에 비해 상대적으로 더 높은 농도를 나타내 었고, 이는 $\mathrm{CH}_{3} \mathrm{SH}$ 성분과 동일한 경향을 보였다.

iso-VA는 계절별 평균농도가 겨울철 $34.237 \mathrm{nmol} /$ $\mathrm{mol}$, 가을 $33.731 \mathrm{nmol} / \mathrm{mol}$, 봄 $31.165 \mathrm{nmol} / \mathrm{mol}$, 여 름 $21.874 \mathrm{nmol} / \mathrm{mol}$ 순으로 겨울철에 가장 높은 농도 를 나타내었다. 또한 돈사방식별로 비교한 결과는 무 창형 스크레퍼방식(J 농장 $)>$ 개방형 슬러리방식(S 농장) > 무창형 슬러리방식(N 농장) > 개방형 스크레 퍼방식(K 농장)순으로 높았다. 그리고 계절별로 각 돈 사방식에 따라 iso-VA 농도를 비교해 본 결과, 겨울, 여름, 가을철에는 무창형 스크레퍼방식에서 높은 농도 를 나타내었다. 그러나 봄철에는 개방형 슬러리방식의 돈사가 다른 돈사에 비해 더 높은 농도를 나타내었다.

$\mathrm{n}-\mathrm{VA}$ 성분의 계절별 평균농도는 겨울철에 20.0833 $\mathrm{nmol} / \mathrm{mol}$ 로 가장 높았고, 다음으로 가을 $17.7355 \mathrm{nmol} /$ $\mathrm{mol}$, 여름 $11.5247 \mathrm{nmol} / \mathrm{mol}$, 봄 $10.6866 \mathrm{nmol} / \mathrm{mol}$ 순으 로 높은 농도를 나타내었다. 그리고 돈사방식별로는 무 창형 슬러리방식 $(\mathrm{N}$ 농장 $)>$ 개방형 슬러리방식 $(\mathrm{S}$ 농장 $)$ $>$ 무창형 스크레퍼방식(J 농장 $)>$ 개방형 스크레퍼방식 (K 농장)순으로 나타났다. 특히 n-VA는 무창형 슬러리 방식의 돈사에서 더 높은 농도를 나타내어 다른 VFA 성분들이 무창형 스크레퍼방식에서 높은 것과는 다른 결과를 나타내었다. 또한 각 돈사방식에 따라 계절별로 구분하여 비교해 본 결과에서는 겨울과 가을철에는 무 창형 슬러리방식에서 높은 농도를 보이지만, 상대적으 로 봄에는 개방형 슬러리방식, 여름철에는 무창형 스크 레퍼방식의 돈사에서 더 높은 경향을 보였다.

이처럼 $\mathrm{VFA}$ 는 겨울철에 높은 농도를 보이고, $\mathrm{n}-\mathrm{VA}$ 를 제외한 PA, n-BA, iso-VA 성분들이 무창형 스크레 퍼방식에서 농도가 더 높은 특징을 나타내었다. 휘발
성 지방산의 농도와 비율이 계절별, 돈사방식별로 차 이를 보이는 것은 분뇨 중의 탄수화물과 단백질이 이 화작용(catabolism)을 거치고, 혐기적 분해과정에서 서 로 다른 혐기성 미생물들의 대사과정을 통해 각기 다 른 대사경로로 생성되기 때문인 것으로 보인다. ${ }^{15}$

\section{5. 돈사 환기 및 분뇨수거 방식별 악취 비교}

일반적으로 돈사는 환기방식에 따라 강제환기를 실 시하는 무창형 돈사와 윈치커튼형의 개방형 돈사로 구분하고 있다. 또 분뇨 수거방식에 따라 스크레퍼와 슬러리방식으로 구분한다. 본 연구에서는 이러한 돈사 의 환기 및 분뇨수거 방식에 따라 악취물질의 농도가 어느 정도 차이를 보이는지 알아보기 위하여 돈사 구 조별로 농도를 비교하였다. 먼저 악취물질의 농도를 환기방식에 따라 비교한 결과를 보면, 모든 성분들이 무창형 돈사가 개방형 돈사에 비해 더 높은 농도를 보이고 있다(Table 6). 표의 결과에서 보듯이 대부분의 돈사에서 미검출된 $\mathrm{DMDS}$ 를 제외한 모든 성분들이 무창형 돈사에서 더 높은 농도를 나타내었다. 특히 무 창형 돈사에서 $\mathrm{NH}_{3}$ 는 1.5 배, 황화합물은 1.4 16.2 배, TMA는 1.1 배, VFA는 1.2 1.4 배 더 높은 농도를 나 타내는 것으로 조사되었다.

또한 분뇨 수거방식에 따라 악취물질의 농도를 상 호 비교한 결과에서는 슬러리방식이 스크레퍼방식에 서 비해 $\mathrm{NH}_{3} 1.3$ 배, $\mathrm{H}_{2} \mathrm{~S} 8.1$ 배, n-VA 1.2 배 더 높 은 농도를 나타내었다. 반면에 스크레퍼방식의 경우 슬러리방식에 비해 $\mathrm{CH}_{3} \mathrm{SH} 1.8$ 배, PA 1.2 배, n-BA 1.3 배 높아 악취물질의 종류에 따라 상호 다른 경향 을 보였다. 그리고 슬러리방식의 돈사에서는 질소와 황계열이 상대적으로 높으나 스크레퍼방식에서는 휘

Table 6. Comparison of odorous compound concentrations ( $\mathrm{nmol} / \mathrm{mol})$ between ventilation system and manure treat

\begin{tabular}{|c|c|c|c|c|c|c|}
\hline \multirow[b]{2}{*}{ Compound } & \multicolumn{3}{|c|}{ Ventilation system } & \multicolumn{3}{|c|}{ Manure treat } \\
\hline & $\begin{array}{c}\text { Enclosed type } \\
\text { (E) }\end{array}$ & $\begin{array}{c}\text { Winch-curtain } \\
\text { (W) }\end{array}$ & $\mathrm{E} / \mathrm{W}$ & $\begin{array}{l}\text { Slurry } \\
\text { (SL) }\end{array}$ & $\begin{array}{l}\text { Scraper } \\
\text { (SC) }\end{array}$ & $\mathrm{SL} / \mathrm{SC}$ \\
\hline $\mathrm{NH}_{3}$ & $20,311.8$ & $13,366.0$ & 1.5 & $19,356.4$ & $14,571.0$ & 1.3 \\
\hline $\mathrm{H}_{2} \mathrm{~S}$ & 472.3 & 29.2 & 16.2 & 462.7 & 56.9 & 8.1 \\
\hline $\mathrm{CH}_{3} \mathrm{SH}$ & 18.0 & 6.9 & 2.6 & 9.1 & 15.9 & 0.6 \\
\hline DMS & 7.1 & 5.3 & 1.4 & 6.1 & 6.3 & 1.0 \\
\hline DMDS & 0.2 & 0.2 & 0.8 & 0.1 & 0.2 & 0.5 \\
\hline TMA & 34.2 & 29.9 & 1.1 & 32.2 & 32.0 & 1.0 \\
\hline PA & 424.5 & 311.0 & 1.4 & 330.6 & 405.8 & 0.8 \\
\hline n-BA & 220.0 & 173.8 & 1.3 & 172.5 & 221.3 & 0.8 \\
\hline iso-VA & 33.8 & 26.3 & 1.3 & 30.7 & 29.7 & 1.0 \\
\hline$n-V A$ & 16.3 & 13.5 & 1.2 & 16.4 & 13.4 & 1.2 \\
\hline
\end{tabular}

Vol. 26, No. 6, 2013 
발성 지방산계열 악취물질의 농도가 상대적으로 높은 경향을 보이고 있다. 이러한 결과는 돈사의 주요 악취 물질인 $\mathrm{NH}_{3}$ 와 $\mathrm{H}_{2} \mathrm{~S}$ 성분이 슬러리방식에서 더 높다고 보고한 선행연구와도 일치하는 결과이다. 이러한 원인 은 슬러리방식의 돈사에서 돈분뇨가 혼합되어 저장되 고, 돈분뇨 수거기간 역시 스크레퍼방식보다 더 길기 때문에 더 높은 농도를 보이는 것으로 추정된다.

\section{6. 돈사 형태별 악취 원인물질 추정}

악취물질은 각 성분별 최소감지농도가 다르기 때문 에 검출된 악취물질의 농도를 기준으로 악취에 기여 하는 정도를 파악하기에 어려움이 있다. ${ }^{16-17}$ 따라서 기 기분석에 의해서 검출된 개별 악취물질의 농도를 각 물질의 최소감지농도로 나누어 준 값인 악취농도지수 (Odor Quotient, OQ)와 총 악취농도지수(Sum of Odor Quotient, SOQ)를 이용하여 악취기여도를 파악함으로 써 주요 악취원인물질을 예측할 수 있다. ${ }^{18}$ 이때 최소 감지농도는 환경부에서 제시한 기준을 적용하였다. ${ }^{19}$ $\mathrm{OQ}$ 가 10 이상이면 약한 취기를 느끼고 100 이상이면 취기를 감지한다. 따라서 $\mathrm{OQ}$ 가 100 이상인 성분들은 주요 악취원인물질로서 작용한다고 볼 수 있다. ${ }^{20}$

본 연구에서 분뇨처리방식이 서로 다른 4 개 돈사 에서 악취농도지수와 총악취농도지수 측정 결과를 Table 7에 비교하였다. 그리고 이를 이용하여 악취기 여도를 산출한 결과를 Fig. 5에 나타내었다. 우선 각 돈사방식별 $\mathrm{SOQ}$ 를 상호 비교한 결과, 무창형 스크레 퍼방식 $(\mathrm{J}$ 농장 $)>$ 무창형 슬러리방식 $(\mathrm{N}$ 농장 $)>$ 개방 형 슬러리방식(S 농장) > 개방형 스크레퍼방식 $(\mathrm{K}$ 농 장) 순으로 높았고, 무창형 스크레퍼방식의 돈사가 가 장 높은 악취도를 나타내었다. 또한 각 돈사방식별로 악취지수를 구하여 비교해 본 결과, 무창형 스크레퍼 방식(J 농장)에서는 $\mathrm{n}-\mathrm{BA}$ 의 악취지수가 가장 높았고, 다음으로 iso-VA, TMA, $\mathrm{PA}, \mathrm{CH}_{3} \mathrm{SH}$ 순으로 높은 결

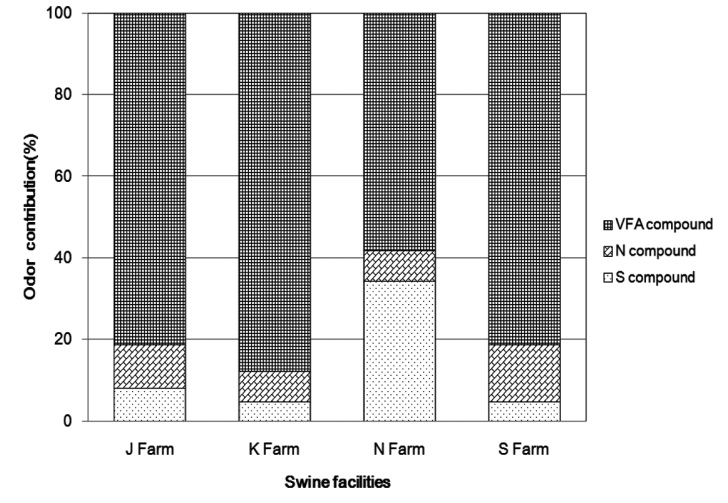

Fig. 5. Odor contribution at the different type of the swine facilities.

과를 보였다. 이때 악취기여도는 VFA가 $81.3 \%$ 로 가 장 높았고, 다음으로 질소계열 $\left(\mathrm{NH}_{3}, \mathrm{TMA}\right) 10.7 \%$, 황 화합물 $8.1 \%$ 의 기여도를 나타내었다.

무창형 슬러리방식(N 농장)에서의 악취지수는 $\mathrm{n}-$ $\mathrm{BA}, \mathrm{H}_{2} \mathrm{~S}$, iso-VA, TMA, n-VA 순으로 높게 나타났다. 그리고 악취기여도는 각각 VFA가 $58.2 \%$, 황화합물이 $34.3 \%$, 질소계열이 $7.5 \%$ 정도로 측정되었다. 특히 무 창형 슬러리방식에서 황화합물의 악취기여도는 다른 돈사의 황화합물 악취기여도가 $10 \%$ 이하인 것에 비 해 훨씬 더 높은 악취기여도를 보이고 있다.

개방형 스크레퍼방식(K농장)에서 각 악취물질의 악 취지수는 비교해 본 결과, n-BA 성분이 가장 높았고, 다음으로 iso-VA, TMA, PA, n-VA 순으로 높았다. 그 리고 개방형 스크레퍼방식에서 이들의 악취기여도는 VFA가 $88.0 \%$ 로 다른 돈사에 비해 더 높고, 그 다음으 로 질소계열 $7.4 \%$, 황화합물 $4.7 \%$ 정도로 측정되었다.

개방형 슬러리방식(S 농장)의 악취지수를 비교해 본 결과에서는 n-BA, iso-VA, TMA, $\mathrm{NH}_{3}, \mathrm{PA}$ 순으로 개방형 슬러리방식 역시 n-BA가 가장 높은 경향을 보

Table 7. Sum of Odor Quotient at the different type of the swine facilities

\begin{tabular}{|c|c|c|c|c|c|c|}
\hline \multirow{2}{*}{ Swine } & \multirow{2}{*}{ SOQ } & \multicolumn{5}{|c|}{ Odor quotient (OQ) } \\
\hline & & $1 \mathrm{st}$ & 2 nd & $3 \mathrm{rd}$ & 4 th & 5 th \\
\hline J Farm & 6,396 & $\begin{array}{c}\text { n-BA } \\
(4,006)\end{array}$ & $\begin{array}{c}\text { iso-VA } \\
(799)\end{array}$ & $\begin{array}{l}\text { TMA } \\
(460)\end{array}$ & $\begin{array}{c}\text { PA } \\
(256)\end{array}$ & $\begin{array}{c}\mathrm{CH}_{3} \mathrm{SH} \\
(252)\end{array}$ \\
\hline N Farm & 5,479 & $\begin{array}{c}\text { n-BA } \\
(2,280)\end{array}$ & $\begin{array}{c}\mathrm{H}_{2} \mathrm{~S} \\
(1,710)\end{array}$ & $\begin{array}{c}\text { iso-VA } \\
(555)\end{array}$ & $\begin{array}{l}\text { TMA } \\
(225)\end{array}$ & $\begin{array}{l}\text { n-VA } \\
(187)\end{array}$ \\
\hline K Farm & 3,394 & $\begin{array}{c}\text { n-BA } \\
(2,316)\end{array}$ & $\begin{array}{c}\text { iso-VA } \\
(388)\end{array}$ & $\begin{array}{l}\text { TMA } \\
(180)\end{array}$ & $\begin{array}{c}\text { PA } \\
(150)\end{array}$ & $\begin{array}{l}\text { n-VA } \\
(131)\end{array}$ \\
\hline S Farm & 4,480 & $\begin{array}{c}\text { n-BA } \\
(2,666)\end{array}$ & $\begin{array}{c}\text { iso-VA } \\
(677)\end{array}$ & $\begin{array}{l}\text { TMA } \\
(428)\end{array}$ & $\begin{array}{l}\mathrm{NH}_{3} \\
(203)\end{array}$ & $\begin{array}{c}\text { PA } \\
(161)\end{array}$ \\
\hline
\end{tabular}


였다. 또한 $\mathrm{NH}_{3}$ 의 악취지수는 다른 돈사에서는 낮은 악취지수를 보인 반면에 개방형 슬러리방식에서는 높 게 나타내었다. 그리고 악취기여도는 VFA가 $81.3 \%$, 질 소계열이 $14.1 \%$, 황화합물이 $4.6 \%$ 순으로 나타내었다.

일반적으로 돈사의 주요 악취 원인물질은 질소와 황 계열로 알려져 있다. 그러나 본 연구에서는 2010년 악취공정시험방법에 새롭게 추가된 VFA의 악취기여 도가 질소와 황계열에 비해 훨씬 높은 결과를 나타내 었다. 이는 휘발성 지방산이 돈사에서 관리가 필요한 주요 악취물질임을 의미한다. 따라서 돈사의 악취 문 제 해결 및 악취 저감을 위해서는 질소와 황화합물 계열은 물론 휘발성 지방산 물질의 관리가 함께 이루 어져야 할 것으로 사료된다.

\section{4. 결 론}

제주지역 양돈시설의 돈사 환기방식과 분뇨 수거방 식이 다른 4 개소에서 주요 악취물질 배출특성과 각 돈사의 악취기여도를 조사하였다. 계절별로 암모니아, 트리메틸아민, 황화합물, 휘발성 지방산 10 종의 악취 물질 농도를 측정한 결과, 4 개 돈사 모두 겨울철에 높은 농도를 나타내었다. 또 이들 악취물질의 농도를 돈사방식별로 비교한 결과에서는 모든 성분들이 무창 형 스크레퍼방식과 무창형 슬러리방식 돈사에서 높은 농도를 나타내었다.

돈사 환기방식별로 농도를 비교한 결과, 무창형이 개방형 돈사에 비해 대부분 높은 농도를 보였다. 그리 고 분뇨 수거방식별로는 슬러리방식이 스크레퍼방식 돈사에 비해 질소와 황계열 악취물질이 높으나 스크 레퍼방식에서는 VFA 계열의 악취물질의 농도가 상대 적으로 높은 것으로 조사되었다.

또한 각 돈사 유형별로 악취기여도를 조사한 결과, 측정한 모든 돈사에서는 VFA 성분의 악취기여도가 높고, 무창형 슬러리방식에서는 황화합물의 악취기여 도가 높게 나타나는 경향을 보였다. 이처럼 제주지역 돈사의 경우, 전체적으로 휘발성 지방산에 의한 악취 기여도가 높은 경향을 보여 질소와 황 계열 외에도 휘발성 지방산을 주요 악취물질에 포함시켜 관리할 필요가 있음을 확인할 수 있었다.

\section{감사의글}

본 논문은 농촌진흥청 공동연구사업(과제번호: $\mathrm{PJ} 907172)$ 의 지원에 의해 이루어진 것이며 이에 감사
를 드립니다.

\section{참고문헌}

1. Y. S. Oh, K. H. Kim, Y. S. Koo, M. S. Kim, M. J. Seol, S. S. Chon, Y. J. Choi and D. H. Ahn, Kor. J. Odor Res. Eng., 5(1), 1-9 (2006).

2. Ministry of Environment, 'Actual Condition Survey of Public Grievance on Offensive Odor Emission in 2011', 2012.

3. A. Yasuhara, K. Fuwa and M. Jimbu, Agric. Biol. Chem., 48, 3001-3010 (1984).

4. S. B. Yang, Y. M. Jung, H. W. Seo and H. J. Kim, 'Sensuous Measurement of Offensive Odor Substances', p1-2, Bok Publishing, 1998.

5. M. K. Schenk and J. Wehrmanna, Plant soil, 52, 403414 (1979).

6. V. Blanes-Vidal, M. N. Hansen, A. P. S. Adamsen, A. Feilberg, S. O. Petersen and B. B. Jensen, Atmos. Environ., 43, 2997-3005 (2009).

7. R. I. Mackie, P. G. Stroot and V. H. Varel, J. Anim. Sci., 76, 1331-1342 (1998).

8. D. H. O'Neill and V. R. Phillips, J. Agric. Eng. Res. 53, 23-50 (1992).

9. Y. K. Jang, K. P. Song, H. J. Kim and Y. H. Yoo, Environ. Imp. Asses. 13(1), 33-40 (2004).

10. Y. H. Yoo, T. L. Kim, J. W. Jeong, H. C. Choi, J. I. Song, C. B. Yang, Y. K. Jang, H. J. Kim and K. P. Song, J. Lives. Hous. \& Env. 11(1), 45-54 (2005).

11. R. N. Coleman, J. J. R. Feddes and B. S. West, Can. Soc. Anim. Prod. Chilliwack (Abstract), (1991).

12. G. A. Nordstrom and J. B. McQuitty, 'Manure Gases in the Animal Environment', Department of Agricultural Engineering, University of Alberta, 1976.

13. D. R. Headon, and G. Walsh, 'Biological control of pollutants principle of pig science. In biotechnology in the feed industry', D. J. A. Cole, J. Wiseman, And M. A. Varley, Nottingham University press, Nottingham, U.K., 1994.

14. J. M. Jeon, B. R. Seo, D. Hur, M. H. Jeong and S. G. Seo, Kor. J. Odor Res. Eng., 6(1), 10-19 (2007).

15. S. Rappert and R. Muller, Waste Manage., 25(9), 887907 (2005).

16. S. J. Park, T. H. Min and G. S. Heo, Kor. J. Odor Res. 
Eng., 4(4), 216-222 (2005).

17. B. J. Song, J. E. Jung, S. R. Jung and G. W. Ji, J. Kor. Soc. Was. Mana., 21(2), 107-116 (2004)

18. H. J. Ko, K. Y. Kim, H. T. Kim, M. S. Ko, T. Higuchi and M. Umeda, J. Anim. Sci., 50(3), 391-400 (2008).
19. Ministry of Environment, 'Control Manual of Offensive Odor Substances’, p18-19, 2007.

20. J. M. Jeon, Y. S. Seo, M. H. Jeong, H. S. Lee, M. D. Lee, J. S. Han and B. W. Kang, Kor. J. Odor Res. Eng., 9(2), 80-89 (2010) 